\title{
Climate Change: Seed Production and Options for Adaptation
}

\author{
John G. Hampton ${ }^{1}$ * , Anthony J. Conner ${ }^{2}$, Birte Boelt ${ }^{3}$, Thomas G. Chastain ${ }^{4}$ \\ and Phil Rolston 1,2 \\ Seed Research Centre, Lincoln University, Lincoln 7647, New Zealand; phil.rolston@agresearch.co.nz \\ AgResearch Ltd., Private Bag 4749, Christchurch 8140, New Zealand; tony.conner@agresearch.co.nz \\ Department of Agroecology, Aarhus University, DK-4200 Slagelse, Denmark; birte.boelt@agro.au.dk \\ Department of Crop and Soil Science, Oregon State University, Corvallis, OR 97331-3002, USA; \\ thomas.chastain@oregonstate.edu \\ * Correspondence: john.hampton@lincoln.ac.nz; Tel.: +64-3-423-0909
}

Academic Editor: Annelie Holzkämper

Received: 8 April 2016; Accepted: 21 July 2016; Published: 26 July 2016

\begin{abstract}
Food security depends on seed security and the international seed industry must be able to continue to deliver the quantities of quality seed required for this purpose. Abiotic stress resulting from climate change, particularly elevated temperature and water stress, will reduce seed yield and quality. Options for the seed industry to adapt to climate change include moving sites for seed production, changing sowing date, and the development of cultivars with traits which allow them to adapt to climate change conditions. However, the ability of seed growers to make these changes is directly linked to the seed system. In the formal seed system operating in developed countries, implementation will be reasonably straight forward. In the informal system operating in developing countries, the current seed production challenges including supply failing to meet demand and poor seed quality will increase with changing climates.
\end{abstract}

Keywords: abiotic stress; adaptation; agriculture; climate change; seed production; seed quality; seed systems

\section{Introduction}

The seed industry is the cornerstone of global food security; food security depends on seed security [1]. The global seed market is currently around US\$ 54 billion [2]. Domestically, the largest seed market is in the USA (US\$ 14 billion), followed by China (US\$ 11.9 billion), France (US\$ 3.4 billion), Brazil (US\$ 3.1 billion) and Canada and India (each US\$2.5 billion). Forty countries have domestic seed markets of US\$ 100 million or greater, but others rely heavily on imports to supply their seed needs [2].

Seed worth US\$ 10.9 billion was imported by 125 countries in 2013 [2]. The international seed market has tripled over the last three decades driven mainly by the evolution of multinational seed companies, the increased availability of F1 hybrids, protection of intellectual property, an increasing use of counter-season production, and the development of genetically engineered crops [3,4]. In US dollar values, seed exports are dominated by three countries: France, the Netherlands, and the USA. Outside Europe and the Americas, only China, Japan, Australia, New Zealand, South Africa, Thailand, and Turkey make the list of the largest twenty-five seed exporting nations [2].

The past fifty years have seen seed yield increases for the world's major crops of $1 \%-3 \%$ per year [1], due largely to genetic gains obtained with plant breeding [5,6], but also to improved agronomic inputs and specialized management systems [1]. Can these seed yield increases continue given that climate change will have direct impacts on land, water, temperature, atmospheric $\mathrm{CO}_{2}$, and weather patterns [7]? These changes must impact agricultural activities [8], although there is debate as to 
whether the impacts will be negative or positive. Some authors $[9,10]$ concluded that the overall impact of climate change on agriculture is expected to be negative, threatening global food security, whereas others (e.g., [11]) considered that global crop production could increase by approximately $50 \%$ by 2050 without extra land. However, the latter authors did stress that a large proportion of these yield increases will need to be delivered via plant breeders through the release of new cultivars adapted to cope with a changing environment $[6,12,13]$. Seed is the basic and most vital input of agriculture [14], and the seed industry must be able to continue to deliver the quantities of quality seed required for this purpose. Climate change poses several challenges for the continued production of high quality seed [15]. In this review, we examine the effects of climate change on seed production and explore options for adaptation of seed production in response to climate change, with a focus on the effects of increased $\mathrm{CO}_{2}$, increased temperature, and their interaction.

\section{Seed Production}

\subsection{Seed Yield: Arable Crop Species}

The impacts of changing climate and climate variability on seed production of arable crops such as rice, soybean, cotton, and peanut has been recently reviewed [15]. Enrichment of atmospheric $\mathrm{CO}_{2}$ is likely to increase seed yields of C3 arable crops (e.g., wheat) by between $11 \%$ and 30\% but leave yields of $C 4$ crops (e.g., maize) unchanged [11,16]. Yield increases are usually because of a greater number of seeds per unit area [17-19] as a result of increased resource use efficiency for radiation, water, and nitrogen [20]. Elevated $\mathrm{CO}_{2}$, through decreasing stomatal conductance, increases water use efficiency [15]. In water stress conditions, this may allow plants to retain more seeds, but yields will always be lower compared to those in non-resource stress environments [15]. Sometimes there is also an increase in seed mass [21], although the effects of elevated $\mathrm{CO}_{2}$ on seed mass are highly variable [22].

Elevated temperature accelerates various aspects of plant metabolism and changes the rate of organ development, respiration, senescence, and source-sink relationships [23]. Most arable crop species are vulnerable to heat stress both pre- and post-fertilization, and any exposure to temperatures above the optimum for the species can result in significant seed yield losses [24-26] with the extent of the reduction in individual seed yield components depending on the timing and duration of the temperature stress experienced. Temperature increases, which reduce seed number, accelerate seed growth rate, reduce the duration of seed filling, and sometimes reduce seed mass [15] can, therefore, negate any positive seed yield responses to increased $\mathrm{CO}_{2}$.

\subsection{Seed Yield: Temperate Pasture Species}

In contrast to the many reports of the effects of elevated $\mathrm{CO}_{2}$ and high temperature on seed yield in arable crop species, little is known about the response of the temperate grass and forage legume species which underpin much of the world's milk, meat, and wool industries [27]. In white clover (Trifolium repens $\mathrm{L}$.), increasing $\mathrm{CO}_{2}$ concentration has been reported to increase flower numbers [28-30] and seeds per flower but not seed mass or seed yield [30]. In perennial ryegrass (Lolium perenne L.), elevated $\mathrm{CO}_{2}$ decreased the time to ear emergence in one cultivar but increased the time to ear emergence by up to 10 days in four cultivars [31]. It also increased seed head numbers in a pasture sward, but not seeds per spikelet, seed mass [29], and seed yield [30]. While there are no reports on other pasture species managed for seed production, there have been a number of reports of seed increases for rangeland Bromus spp. [32-34] following exposure to elevated $\mathrm{CO}_{2}$.

Hikosaka et al. [35] suggested that in grasses and legumes, seed production is limited by nitrogen rather than carbon and that seed yields would be increased only when nitrogen became more available at elevated $\mathrm{CO}_{2}$ levels. In their study, legumes exhibited a more pronounced increase in nitrogen acquisition and enhanced seed production with elevated $\mathrm{CO}_{2}$ than non-leguminous species. Enhanced $\mathrm{CO}_{2}$ has been reported to enhance nodulation and nitrogen fixation [36-38], and thus 
white clover may have been expected to demonstrate a seed yield increase. However, if soil nitrogen was not limiting, this may have negated any nitrogen fixation response [39]. Grass species increase seed production with elevated $\mathrm{CO}_{2}$ by decreasing seed nitrogen concentration as well as increasing acquisition of plant available nitrogen [35].

White clover is generally regarded as a long-day plant, which requires a period of vernalization (cool, short days) before initiating reproductive growth [40]. After vernalization, and at $14 \mathrm{~h}$ or $16 \mathrm{~h}$ day lengths, inflorescence initiation is favored by high $\left(27.5^{\circ} \mathrm{C}\right.$ day $/ 19^{\circ} \mathrm{C}$ night $)$ temperatures $[41,42]$. However, a temperature of $30^{\circ} \mathrm{C}$ with either $14 \mathrm{~h}$ or $18 \mathrm{~h}$ day lengths decreased florets per inflorescence and ovules per floret compared with those which developed at $20^{\circ} \mathrm{C}$ in the same day length [41]. More reproductive buds per stolon and flowers per plant occurred at $26^{\circ} \mathrm{C}$ than at $18^{\circ} \mathrm{C}$, both in a $16 \mathrm{~h}$ day length [43], but there was no change in mean floret or ovule number.

Perennial ryegrass tiller production is optimal at $18-24^{\circ} \mathrm{C}$ [44], and higher temperature, especially at night, can depress tiller production [45], thus potentially reducing seed yield. The initiation of reproductive growth requires a dual induction: vernalization (ca. $6{ }^{\circ} \mathrm{C}$ in short days (primary induction) and then exposure to long days (secondary induction [46]). The optimum temperature during secondary induction is between $12{ }^{\circ} \mathrm{C}$ and $15^{\circ} \mathrm{C}$, and high temperatures at this time can result in devernilization of previously vernalized plants [47]. They can also reduce spikelet numbers [48]. Increasing temperature (range $13-23^{\circ} \mathrm{C}$ ) between spikelet initiation and ear emergence reduced both spikelet and floret number, thus reducing seed yield [49]. Increasing temperature also reduces the time to anthesis and the time for seed development, reducing seed mass [50]. Air temperature just before and after anthesis accounted for $70 \%$ of the variability in perennial ryegrass seed number [51].

\subsection{Seed Yield: Vegetable Species}

Few studies on the effects of elevated $\mathrm{CO}_{2}$ and temperature on vegetable seed production have been reported. Carrot (Daucus carota L.) vegetative growth is increased by elevated $\mathrm{CO}_{2}$ [52-54] although the effect is temperature dependent. At $11-12{ }^{\circ} \mathrm{C}$, elevated $\mathrm{CO}_{2}$ had no effect on carrot growth, but at mean air temperatures of $>25^{\circ} \mathrm{C}$, vegetative biomass was nearly doubled [52]. However, there have been no reports on the effects of elevated $\mathrm{CO}_{2}$ on carrot reproductive growth. Elevated $\mathrm{CO}_{2}$ more than doubled radish (Raphanus sativus L.) vegetative dry matter [55], but the response was temperature dependent, increasing as air temperature increased [52]. In wild radish ( $R$. raphanistrum), elevated $\mathrm{CO}_{2}$ increased flower and seed production [56], but another report found that in the same species, elevated $\mathrm{CO}_{2}$ reduced flower and seed numbers [57].

Increasing mean air temperature from $20^{\circ} \mathrm{C}$ to $26^{\circ} \mathrm{C}$ reduced carrot vegetative biomass, main stem height, and days to first flowering. Umbels per plant were increased at the higher temperature but the number of flowers per umbel was reduced, as was the fertility of the male flowers [58]. When temperature was increased from $20^{\circ} \mathrm{C}$ day $/ 10^{\circ} \mathrm{C}$ night to $30^{\circ} \mathrm{C}$ day $/ 20^{\circ} \mathrm{C}$ night, a $13 \%-20 \%$ reduction in mean carrot seed mass was found [59], which was associated with a reduction in seed filling time rather than any difference in seed relative growth rate. Daytime temperatures of 20 to $30^{\circ} \mathrm{C}$ caused devernalization in radish [60], and a similar response has been recorded in vegetable brassicas [61,62]. Increasing temperature from $17^{\circ} \mathrm{C}$ to $26^{\circ} \mathrm{C}$ significantly reduced radish pod number and seeds per pod [63], and a reduction in cabbage (Brassica oleracea L.) seed yield was associated with increasing temperature during pod setting [64]. Although B. napus L. (canola) is not a vegetable brassica, the negative effects of a $5{ }^{\circ} \mathrm{C}$ temperature increase on seed yield could not be compensated by elevated $\mathrm{CO}_{2}$ [65]. It is likely that this response would also occur in vegetable brassicas.

\section{Plant Reproductive Processes}

The sexual reproductive phase in plants may be altered by both elevated $\mathrm{CO}_{2}$ and temperature [15]. A plant grown at elevated $\mathrm{CO}_{2}$ may be able to invest more resources in flowers [66], but most plants can only tolerate narrow temperature changes which, if exceeded, can reduce seed set and therefore seed yield $[67,68]$. 


\subsection{Flowering Time}

Elevated $\mathrm{CO}_{2}$ can advance, delay, or impose no change on flowering time depending on genotypes and growing conditions [69]. Heat stress can also trigger either early or delayed flowering depending on the species and other environmental conditions [15]. Accelerated flowering may result in reproductive development before the plant has accumulated sufficient biomass resources required for the provisioning of developing seeds [70]. Heat stress can also cause asynchrony between male and female reproductive development [71], leading to problems for hybrid seed production which require that pollen from the male parent line be available when stigmas on the female parent line are receptive to pollen. The effect of elevated temperature in the presence of elevated $\mathrm{CO}_{2}$ on flowering time is not yet known.

\subsection{Floral Organs}

Elevated $\mathrm{CO}_{2}$ has been reported to both increase and decrease flower production $[72,73]$ but to increase the time flowers remain open [66]. Variable responses for nectar production per flower and for nectar sugar composition and concentration have also been reported [66,72]. In one study, elevated $\mathrm{CO}_{2}$ increased the concentration of glucose and fructose and reduced the ratio of sucrose to hexoses [73]. This may change the attractiveness of the nectar to pollinators (large bees such as Bombus spp. prefer sucrose-dominated nectars [74]) and the duration of pollinator visits received by flowers [73]. Heat stress can reduce the number, decrease the size, and cause deformity of floral organs [75] and accelerate stigma and ovule development, reducing the duration for which they are receptive to pollen and pollen tubes [76]. However, elevated temperature can reduce the negative effect of elevated $\mathrm{CO}_{2}$ on the number of flowers produced [73].

\subsection{Pollen}

Exposure to elevated $\mathrm{CO}_{2}$ has been reported to either increase or not change pollen production $[77,78]$ but reduce pollen viability and pollen germination [78]. This decrease in pollen viability may have resulted from a nutrient limitation that developed as $\mathrm{CO}_{2}$ became abundant [79]. Both nitrogen and phosphorous can become limiting under elevated $\mathrm{CO}_{2}$ [80], and a reduction in their availability can reduce pollen quality [79].

The quantity and morphology of pollen, anther dehiscence, and pollen wall architecture, the chemical composition and metabolism of pollen, and pollen viability, germination, and pollen tube growth can all be negatively affected by heat $[70,76]$. Given the great amounts of pollen produced in most plant species, the production decreases recorded may not greatly impact reproductive output [76]. The effect of heat stress will be more important for seed production because of the negative effects on pollen viability, pollen germination, and pollen tube growth rate [77] leading to reduced seed set [68]. Increasing temperature decreased pollen production irrespective of $\mathrm{CO}_{2}$ [78]. However, there was a negative interaction between temperature and $\mathrm{CO}_{2}$ on pollen viability, with the decrease in pollen viability in response to increasing temperature being greater at elevated $\mathrm{CO}_{2}$ than at ambient $\mathrm{CO}_{2}$ levels [81].

\subsection{Pollinators}

Seed production from 87 of the world's leading food and forage crops depends on insect pollination [82], and climate change may be a threat to pollination services [83]. Any changes in nectar production and/or composition could have detrimental effects on the interactions of flowers and their pollinators. For example, a negative effect of elevated $\mathrm{CO}_{2}$ on bumble bee (Bombus terrestris $\mathrm{L}$.) survival has been reported and attributed to a change of sucrose to hexoses ratio (see Section 3.2). However, this effect on longevity was mitigated by increasing temperature [73].

In plant species where elevated $\mathrm{CO}_{2}$ increases floral display (increased flower numbers and longevity), attractiveness to pollinators may be increased, and the increased nectar resources should benefit the populations of bees (and other insects) feeding on the flowers [66]. However, $\mathrm{CO}_{2}$ enhancement can affect bees directly; within honey bee (Apis mellifera L.) hives, the highest flight traffic 
out of the hive is during the period of lowest $\mathrm{CO}_{2}$ concentration [84]; $\mathrm{CO}_{2}$ anaesthetized bees changed from hive to field activities at an earlier age after the treatment and their pollen collection almost ceased [85]. These observations suggest that $\mathrm{CO}_{2}$ enhancement may affect bee foraging behavior [86] and possibly the motivation to forage [87] with negative effects on pollination.

It is likely that pollinators will change their activity patterns as temperature increases because, at least for bees, the thermal properties of their environment determine the extent of their activity [88]. Bees absorb heat at high temperatures and the time taken for thermoregulation comes at the cost of foraging, with a negative consequence for pollination [89] because of reduced efficiency of pollen removal and deposition. However, the current knowledge of the potential consequences of climate change, in particular increasing temperatures on plant/pollinator interactions, is limited. The effects of rising temperatures are more likely to be deleterious to pollinators in the tropics than to those at higher latitudes because the former are living in an environment already close to their optimal temperature while the latter have broader thermal tolerance and are currently living in cooler climates than their physiological optima [90]. A warming environment may actually enhance the performance of insects living at higher latitudes [89].

\section{Genetic Purity of Cultivars}

A critically important impact of climate change on seed production involves the potential loss of genetic quality in open pollinated and $\mathrm{F} 1$ hybrid cultivars. Elevated $\mathrm{CO}_{2}$ and temperature can induce changes in the sexuality in crops plants, including a breakdown in self-incompatibility or male sterility mechanisms. These breeding systems are used in seed production to promote outcrossing in order to maintain a high level of heterozygosity in many open pollinated crops or to guarantee F1 hybrid seed production [91]. Breakdown of these genetic mechanisms results in self-pollination. As a consequence, the genetic integrity of the cultivar is lost and any seed produced will no longer be true-to-type.

Many forage crops, such as clovers and perennial ryegrass, rely on self-incompatibility to maintain outcrossing and heterozygosity within open pollinated populations. A breakdown of self-incompatibility could lead to rapid inbreeding in only a few generations of seed production [91]. This would greatly reduce the frequency of heterozygosity at many loci, resulting in inbreeding depression which will significantly reduce performance of the resulting crop. For seed production in many vegetable crops, some form of male sterility is essential for F1 hybrid seed production. If the male sterile parent (the female parent) from which seed is harvested exhibits a slight reversion toward pollen fertility, then even a low frequency of seed from self-pollination greatly reduces the value of the F1 hybrid seed [91]. In many cases, the loss of male sterility will make the harvested seed worthless due to the loss of heterosis, uniformity, and performance of the subsequent crop.

The breakdown of self-incompatibility or male sterility as a consequence of heat stress (Table 1) results in a major source of pollen contamination for hybrid seed production. A potential solution involves the deployment of a single dominant herbicide resistance gene in the homozygous state in the intended pollen parent. All true hybrid seed harvested from the female parent is then heterozygous for herbicide resistance and any harvested seed arising from self-pollination of the female parent can be eliminated by sensitivity to the herbicide [92].

Table 1. Examples of effects of elevated temperature on the breeding systems in selected crop species.

\begin{tabular}{ccc}
\hline Species & Response to Elevated Temperature & Reference \\
\hline Carrot & Reduced male sterility at $26^{\circ} \mathrm{C}$ & {$[58]$} \\
Brussels sprouts & Breakdown of male sterility above $17^{\circ} \mathrm{C}$ & {$[93]$} \\
Radish & Breakdown of self-incompatibility at $26^{\circ} \mathrm{C}$ & {$[63]$} \\
Alsike clover & Breakdown of self-incompatibility at $32^{\circ} \mathrm{C}$ & {$[94]$} \\
Red clover & Breakdown of self-incompatibility at $40^{\circ} \mathrm{C}$ & {$[95]$} \\
White clover & Breakdown of self-incompatibility at $35^{\circ} \mathrm{C}$ & {$[96]$} \\
Perennial ryegrass & Breakdown of self-incompatibility at $34^{\circ} \mathrm{C}$ & {$[97]$} \\
\hline
\end{tabular}




\section{Seed Quality}

The effects of elevated $\mathrm{CO}_{2}$ and temperature on seed quality have been recently reviewed [22]. The following is therefore a summary of the known responses.

\subsection{Seed Mass}

Seed mass responses to elevated $\mathrm{CO}_{2}$ are highly variable, both among and within species [35]. Increases are greater in legumes than non-legumes, and seed mass increases may result in a decreased seed nitrogen concentration in non-legumes [22]. Increasing temperature may decrease seed mass because of an accelerated seed growth rate and reduced seed filling duration $[98,99]$, but lower seed mass does not necessarily reduce seed germination or vigour [22].

\subsection{Germination}

Seed germination in response to elevated $\mathrm{CO}_{2}$ is also highly variable, with responses varying among species [100]. The reported change in carbon/nitrogen ratio [101] may reduce seed protein content, reducing seed viability by limiting the seed's ability to supply the amino acids required for protein synthesis during embryo growth [22]. Conversely, elevated $\mathrm{CO}_{2}$ increases ethylene production [100] which can promote germination in many species. High temperature stress before seeds reach physiological maturity can reduce germination by inhibiting the ability of the plant to supply the assimilates necessary to synthesize the storage compounds required for the germination process [22], and/or the seeds suffer physiological damage to the extent that the ability to germinate is lost [102].

\subsection{Seed Vigour}

Nothing is known concerning the effects of elevated $\mathrm{CO}_{2}$ on seed vigour, but seed vigour can be significantly reduced by high temperature stress both before and after physiological maturity [22]. High temperatures induce or increase the physiological deterioration of seeds [102], and limited evidence suggests that only short periods of high temperature stress at critical stages of seed development are required to reduce seed vigour [22].

\section{Post Seed Harvest}

Internationally, present seed losses as a result of poor drying and storage are conservatively estimated to be between $10 \%$ and $40 \%$ depending on location, drying method, storage conditions, and species [103]. Information on seed drying, seed storage and maintaining seed viability is presented in $[104,105]$.

Increasing atmospheric $\mathrm{CO}_{2}$ is unlikely to have any negative effects on seed viability in storage. Seeds produce $\mathrm{CO}_{2}$ as a byproduct of their respiration, and the accumulation of $\mathrm{CO}_{2}$ from this source within sealed containers has been used to control seed storage insect pests [106], as has flushing of sealed containers with $\mathrm{CO}_{2}$ [103].

Because seeds are good insulators they can absorb radiant heat from the sun, so that seed temperature can often be $10-12{ }^{\circ} \mathrm{C}$ higher than ambient air temperature [104]. Elevated air temperature and clear, cloudless days immediately prior to and/or during seed harvest can therefore lead to heating damage, even in seed lots harvested at a seed moisture content considered 'safe' for the species (e.g., $140-150 \mathrm{mg} / \mathrm{g}$ for wheat seed). For example, at an air temperature of $32^{\circ} \mathrm{C}$, perennial ryegrass at harvest had a seed temperature of $41^{\circ} \mathrm{C}$ [104]. If this 'hot' seed is not cooled quickly before being processed or placed into storage, storage fungi will proliferate, resulting in further heating of the seed lot and the rapid loss of seed quality [104].

In countries where sun drying of seed is practiced, elevated ambient temperatures will increase the risk of rapid seed quality deterioration, again by increasing seed temperatures to levels $\left(60-70{ }^{\circ} \mathrm{C}\right)$, 
which reduce germination. However, this damage can be mitigated by shading the seed from direct radiation from the sun during the drying process.

The effects of temperature on uncontrolled seed storage have been long known. For seed at moisture contents between $50 \mathrm{mg} / \mathrm{g}$ and $140 \mathrm{mg} / \mathrm{g}$, seed storage life is generally doubled by every $5{ }^{\circ} \mathrm{C}$ decrease in storage temperature [107]. Increased ambient temperatures would, therefore, tend to reduce seed storage life, although this may be tempered because of the relationship between temperature and relative humidity ( $\mathrm{RH})$. Seeds are hygroscopic, meaning that air brought into contact with the seed exchanges water with the seed until the seed moisture content and water content of the air reach a balance: the equilibrium moisture content. In temperate environments, the water holding capacity of air is temperature dependent, so that RH decreases as temperature increases. Higher air temperatures may therefore assist in preventing seed moisture content in uncontrolled storage increasing to levels not 'safe' for storage [104].

\section{Options for Adaptation}

\subsection{Moving Sites for Seed Production}

Climate change modelling predicts gains in potential agricultural land globally [108], particularly in North America, Northern Europe, and the Russian Federation because of longer sowing windows and more favorable growing conditions as temperature increases. For example, it has been suggested that climate warming in Europe would expand the area of all cereals, and both cooler season (pea, canola) and warmer season (soybean, sunflower) seed crops northwards, while production would decrease in the Mediterranean region [20]. Significant losses in agricultural land are predicted for northern and Southern Africa due to a worsening of growing conditions from increased heat and moisture stress [108].

It may therefore be necessary to move seed production to the limits of adaptation, either in latitude or in elevation in order to reduce the chances of environmental stress negatively affecting seed yield and quality [22]. The impact of climate change on cabbage seed production in north-western India between 1981 and 2004 has been reported [64]. During this time, seed yield of the same cultivar decreased by around $40 \%$, and this was associated with increasing minimum and maximum temperature during pod setting; when a mean maximum temperature exceeded $25^{\circ} \mathrm{C}$, a sharp decline in seed yield was observed. These authors considered that cabbage seed production would need to be shifted northward to minimize the effect of increasing temperature.

For the seed industries of North America, China, India, the countries of northern Europe, the southern South American countries, New Zealand, and Australia, moving seed production north or south will be possible, but will depend on water availability and the extent of competition for land use from other agricultural production [109]. However, the seed industries in countries at lower latitudes, particularly in Africa, may not have this option, forcing them to import even more of their seed requirements.

\subsection{Changing Sowing Date}

Changing sowing date to avoid the detrimental effects of high temperatures at flowering and during seed set has been recommended as an adaptation strategy for climate change [15]. A shift in sowing dates (e.g., earlier sowing of spring crops to avoid hot and dry periods during summer) is one of the expected adaptation responses to climate change in the cooler zones of Europe [110], while for wheat in northwest India, sowing date would need to be advanced by six days per degree rise in temperature [111]. One impact of increased temperatures has been the earlier onset of spring, and as a result of warmer spring temperatures in the northern Great Plains of the USA, earlier maize [112] and wheat [113] sowings have been possible, leading to significant yield increases by avoiding temperature stress during seed filling. 
A day/night temperature of $38^{\circ} \mathrm{C} / 21^{\circ} \mathrm{C}$ reduced pollen viability and seed set in sorghum [114]. These authors used years of climate data from one site in Queensland, Australia, and showed that the number of days when the maximum temperature was greater than $38{ }^{\circ} \mathrm{C}$ over the time of pollen production was greatest from mid-December to mid-January. There were many occasions (approximately 50\%) with at least one such day, but many less (approximately 10\%) with more than four days exceeding $38^{\circ} \mathrm{C}$ during pollen production. Their conclusion was that for this site, sowings in mid-November were most at risk of experiencing high temperature during pollen formation, and that the risks would be lower for early November and early December sowings. They also made the point that as high temperature occurrences can occur over a wide time frame during summer, other sowing times would not be totally immune.

While changing sowing date to avoid/reduce the risk of temperature stress effects on seed yield and seed quality may be an effective management option, the effects of other factors will also need to be considered. These include soil temperature effects on germination and emergence [115], day length responses, particularly premature flowering in short days [116], the possibility of frosts during flowering [117], water availability [118], and increased weed, pest, and disease pressure [16,20].

\subsection{Plant Breeding}

Plant breeding has been a success story in increasing yields over the last fifty years [11], and will continue to be vitally important in developing cultivars adapted to climate-change conditions $[6,15]$. The desired traits include drought and temperature stress resistance, resistance to pests and diseases, and the ability to cope with salinity and water logging [6]. This can be achieved using a combination of conventional, molecular and transgenic approaches [119]. Conventional breeding methodologies, particularly phenotyping and double haploid technology, will play important roles in accelerating the development of climate-adapted germplasm [120]. Molecular technologies, including the use of marker-trait associations and genome-wide selection, are providing opportunities to develop germplasm with tolerance to multiple abiotic and biotic stresses [121]. Transgenic approaches are also being investigated [122]. An additional important target trait for seed production in highly heterozygous open pollinated and F1 hybrid cultivars will be more stable alleles conferring self-incompatibility and male sterility under elevated temperatures.

The adverse effects of heat stress can be mitigated by developing crop plants with improved thermotolerance [123]. Genetic diversity for heat tolerance has already been demonstrated for crops such as wheat [124], soybean [125], peanut ([126,127], Table 2), bean [128], cowpea [129], and cotton [130]. Breeders could also consider incorporating photoperiod insensitivity [131] so that seed filling can begin before the onset of the highest temperatures [132]. Both landraces and, when available, wild relatives contain substantial genetic variation, some of which will allow breeding for high temperature resistance [110].

Table 2. Total dry matter and pod and seed dry weight of four peanut genotypes grown at air temperatures of $28 / 22{ }^{\circ} \mathrm{C}$ (mean $25^{\circ} \mathrm{C}$ ) or $38 / 22^{\circ} \mathrm{C}$ (mean $30^{\circ} \mathrm{C}$ ) from 21 to 90 days after planting (adapted from [127]).

\begin{tabular}{|c|c|c|c|c|c|c|c|c|c|}
\hline & \multicolumn{4}{|c|}{ Susceptible $^{1}$} & \multicolumn{4}{|c|}{ Tolerant $^{2}$} & \multirow[b]{3}{*}{ SED (28 df) } \\
\hline & \multicolumn{2}{|c|}{ Genotype 1} & \multicolumn{2}{|c|}{ Genotype 2} & \multicolumn{2}{|c|}{ Genotype 3} & \multicolumn{2}{|c|}{ Genotype 4} & \\
\hline & $28 / 22{ }^{\circ} \mathrm{C}$ & $38 / 22{ }^{\circ} \mathrm{C}$ & $28 / 22{ }^{\circ} \mathrm{C}$ & $38 / 22{ }^{\circ} \mathrm{C}$ & $28 / 22{ }^{\circ} \mathrm{C}$ & $38 / 22{ }^{\circ} \mathrm{C}$ & $28 / 22{ }^{\circ} \mathrm{C}$ & $38 / 22{ }^{\circ} \mathrm{C}$ & \\
\hline $\begin{array}{l}\text { Total dry matter } \\
\text { (g/plant })\end{array}$ & 148.9 & 114.3 & 179.6 & 115.9 & 158.6 & 129.7 & 185.4 & 138.0 & $4.56^{* * *}$ \\
\hline $\begin{array}{l}\text { Pod dry matter } \\
\text { (g/plant })\end{array}$ & 78.0 & 45.4 & 59.4 & 12.8 & 73.5 & 53.6 & 40.2 & 28.9 & $3.40^{* * *}$ \\
\hline $\begin{array}{l}\text { Seed dry weight } \\
\text { ( } \mathrm{g} / \text { plant })\end{array}$ & 63.8 & 26.6 & 45.0 & 10.0 & 61.7 & 42.8 & 36.9 & 28.7 & $2.51^{* * *}$ \\
\hline
\end{tabular}


Potential genetic strategies to improve plant heat-stress tolerance include traditional and contemporary molecular breeding protocols and transgenic approaches $[123,133,134]$. Heat stress tolerance is a polygenic character, and this makes it difficult to identify heat tolerance related traits by classical genetics. Bita and Gerats [134] reviewed strategies for crop improvement for heat stress tolerance and concluded there was a need for molecular biologists, plant physiologists, and plant breeders to work collaboratively to enable the identification of tolerance genes and elucidation of functional relationships between genotype and observed phenotypes. This would provide a system-wide phenome to genome analysis [123] allowing accurate trait mapping, introgression of superior alleles, or cloning of major quantitative trait loci (QLTs). Genome-wide analyses have started to provide some candidate genes involved in thermotolerance [135-138]. Understanding the genetic basis of heat tolerance is essential to allow breeders to facilitate the transfer of genes for heat tolerance to commercial cultivars $[123,134]$.

A similar call has been made for further research to assess crop yield responsiveness to elevated $\mathrm{CO}_{2}$ [12]. Several studies $[139,140]$ suggest that traditional plant breeding has tended to select against $\mathrm{CO}_{2}$ responsiveness. Ainsworth et al. [13] identified the need to better understand the mechanisms of yield responses to $\mathrm{CO}_{2}$, to assess the genetic diversity available for improved responsiveness, and to establish efficient schemes to select for adaptation to elevated $\mathrm{CO}_{2}$. These authors have proposed a new generation of free-air concentration enrichment experiments focused on adapting crops to elevated $\mathrm{CO}_{2}$ using the tools of molecular genetics.

Drought tolerance is also a highly desirable trait, and several studies have shown that cereal crops such as rice, maize and wheat and their sexually compatible wild relatives have substantial untapped genetic potential for breeding, including traits for withstanding drought $[141,142]$. Other studies have identified genetic markers and physiological traits associated with drought tolerance [141]; barley cultivars, for example, have been reported to have a 19-fold difference in the expression of genes associated with drought tolerance [143]. Drought tolerant maize cultivars developed through conventional breeding have been released in the USA [144]. The ability of genetic engineering to increase the ability of crops to withstand drought is unclear [141].

Climate-adapted germplasm will often have to incorporate packages of traits [119]. In Southern Africa this will be tolerance to drought stress at elevated temperatures [119], while in many parts of Asia, tolerance to both drought and water logging is becoming important [145].

\section{Seed Systems}

The ability for seed growers to make the adaptations required resulting from climate change is directly linked to the seed system within a country. In the formal system which operates in developed countries, where commercial seed companies supply most seed required, legislation and supporting activities are fully developed, and annual replacement of cultivars is high, growers will have access to seed of newly released cultivars with the desired traits whose genetic purity is maintained through seed certification. Seed crops will continue to be grown under contract for a seed company, and seed quality standards will continue to be met. Growers in developed countries are able to pay for the required climate change adaptations measures [15], can afford to insure for crop losses due to extreme weather events such as flooding, hail, or high winds, and have the expertise and/or access to expert advice to allow them to implement crop management changes.

The situation is vastly different in the developing world. As Singh et al. [15] put it, "for poor countries there is no climate safety net". In most developing countries, where there are few commercial seed companies, legislation and supporting activities are not developed and annual seed replacement is very low, informal sources still provide a large proportion of seeds to be sown, either saved from a farmer's own harvest or purchased from a local market (e.g., [146,147]). The use of improved seed (either certified or local selection) is commonly under $20 \%$. However, plant breeders have been actively working towards producing cultivars better able to cope with climate change. The Drought Tolerant Maize for Africa project [145] has produced new drought tolerant hybrids [148], and drought tolerant 
germplasm which also has a higher level of tolerance to higher temperatures is also available [149]. Similarly, the Program for Africa's Seed Systems is seeking to promote the development of seed systems that deliver improved, locally adapted crop varieties to small-scale farmers and the uptake and use of released cultivars [150]. The Millennium Seed Bank, in collaboration with the Global Crop Diversity Trust, is collecting, protecting, and preparing the wild relatives of the world's most important food crops in a form that breeders can readily use to produce cultivars adapted to future climatic conditions that farmers in the developing world will soon be encountering [151]. However, the question remains, can seed of cultivars adapted to climate change be produced in (i) developed countries at a price which farmers in developing countries could afford to pay or (ii) in developing countries in sufficient quantities to meet local demand? In 2013, African countries imported around 40,000 tons of field crop and vegetable seed while countries in Asia imported 79,000 tons [2], only minor contributions to the total demand. For many countries in Africa for example, the annual seed demand exceeds production, and over $80 \%$ of seeds which are available to the farming community are not certified and are of unknown quality [150]. Farmers' access to quality seed of a diverse range of adapted cultivars is still impeded by insufficient and inefficient seed production and distribution systems, poor seed quality assurance, inadequate seed policies, and seed price $[15,119,150]$. Many of the obstacles within seed production can be overcome [119], but the time which will be required to do so is cause for concern. The challenges for seed production which exist presently in developing countries will increase with changing climates [15].

\section{Conclusions}

Are there options for adaptation of seed production in response to climate change? There is no escaping the conclusion that the ability of the world's seed industry to supply the quantities of quality seed required for agricultural production will be impaired unless the seed industry undergoes change. Any increases in seed yield in response to elevated $\mathrm{CO}_{2}$ will be negated by temperature and water stress, and high temperatures at critical times during seed development will reduce seed quality. The genetic quality of cultivars in open pollinated and F1 hybrid crops is also likely to be reduced. Heat stress in particular can induce a breakdown of male sterility and self-incompatibility mechanisms. This results in self-pollinations and the undesired consequences of a reduction in heterozygosity, loss of heterosis, and potential inbreeding depression during seed production. New cultivars with the ability to produce under abiotic stress (including water stress, elevated temperatures, and increased pest and disease pressure) are a must, but while they will be able to be readily utilized in the developed world, their use in developing countries will have many obstacles to overcome. Seed companies in the formal system of developed countries will be more readily able to meet this new demand than those in the informal system of developing countries. Seed crop management options include moving seed production either in latitude (north or south) or in elevation (highlands and mountainous regions) in order to reduce the frequency of abiotic stress and altering sowing date to avoid high temperate stress during seed development [22]. The ability of seed producing countries to do so will depend on their distance from the equator in both hemispheres. There are major challenges ahead for the seed industry. How effectively they can be mitigated will have a major impact on the need to achieve food security internationally.

Author Contributions: John Hampton prepared the initial draft of the manuscript. Tony Conner, Birte Boelt, Tom Chastain and Phil Rolston commented on the draft and provided amendments which were incorporated into the final version. John Hampton edited the manuscript.

Conflicts of Interest: The authors declare no conflict of interest.

\section{References}

1. Bruins, M. The evolution and contribution of plant breeding to global agriculture. In Proceedings of the Second World Seed Conference, Rome, Italy, 8-10 September 2009; pp. 18-31. 
2. ISF. International Seed Federation website. Available online: https://www.worldseed.org (accessed on 9 March 2016).

3. Le Buanec, B. Evolution of the seed industry during the past three decades. Seed Test. Int. 2007, 134, 6-10.

4. Hampton, J.G. Maintaining capacity in seed technology and seed testing. In Proceedings of the Second World Seed Conference, Rome, Italy, 8-10 September 2009; pp. 187-194.

5. Le Buanec, B. Opening address. In Proceedings of the Second World Seed Conference, Rome, Italy, 8-10 September 2009; pp. 13-16.

6. Ceccarelli, S.; Grando, S.; Maatougui, M.; Michael, M.; Slash, M.; Haghparast, R.; Rahmanian, M.; Taheri, A.; Al-Yassin, A.; Benbelkacem, A.; et al. Plant breeding and climate changes. J. Agric. Sci. 2010, 148, $627-637$. [CrossRef]

7. Kurukalasuriya, P.; Rosenthal, S. Climate Change and Agriculture: A Review of Impacts and Adaptations; World Bank: Washington, DC, USA, 2013.

8. Eitzinger, J.; Orlandini, S.; Stefanski, R.; Naylor, R.E.L. Climate change and agriculture: Introductory editorial. J. Agric. Sci. 2010, 148, 499-500. [CrossRef]

9. Nelson, G.C.; Rosegrant, M.W.; Koo, J.; Robertson, R.; Sulser, T.; Zhu, T.; Ringler, C.; Msangi, S.; Palazzo, A.; Batka, M.; et al. Climate Change: Impact on Agriculture and Costs of Adaptation; International Food Policy Research Institute: Washington, DC, USA, 2009.

10. Challinor, A.J.; Watson, J.; Lobell, D.B.; Howden, S.M.; Smith, D.R.; Chhetri, N. A meta-analysis of crop yield under climate change and adaptation. Nat. Clim. Chang. 2014, 4, 287-291. [CrossRef]

11. Jaggard, K.W.; Qi, A.; Ober, E.S. Possible change to arable crop yields by 2050. Philos. Trans. R. Soc. B Biol. Sci. 2010, 365, 2835-2851. [CrossRef] [PubMed]

12. Ainsworth, E.A.; Rogers, A.; Leakey, A.D.B. Targets for crop biotechnology in a future high- $\mathrm{CO}_{2}$ and high-O world. Plant Physiol. 2008, 147, 13-19. [CrossRef] [PubMed]

13. Ainsworth, E.A.; Beier, C.; Calfapietra, C.; Ceulemans, R.; Durand-Tardif, M.; Farquhar, G.D.; Godbold, D.L.; Hendrey, G.R.; Hickler, T.; Kaduk, J.; et al. Next generation of elevated $\mathrm{CO}_{2}$ experiments with crops: A critical investment for feeding the future world. Plant Cell Environ. 2008, 31, 1317-1324. [CrossRef] [PubMed]

14. Maity, A.; Pramanik, P. Climate change and seed quality: An alarming issue in crop husbandry. Curr. Sci. 2013, 105, 1336-1338.

15. Singh, R.P.; Prasad, P.V.V.; Reddy, K.R. Impacts of changing climate and climate variability on seed production and seed industry. Adv. Agron. 2013, 118, 49-110.

16. Hatfield, J.L.; Boote, K.J.; Kimball, B.A.; Ziska, L.H.; Izaurralde, R.C.; Ort, D.; Thomson, A.M.; Wolfe, D. Climate impacts on agriculture: Implications for crop production. Agron. J. 2011, 103, 351-370. [CrossRef]

17. Qaderi, M.M.; Reid, D.M. Growth and physiological responses of canola (Brassica napus) to UV-B and $\mathrm{CO}_{2}$ under controlled environment conditions. Physiol. Plant. 2005, 125, 247-259. [CrossRef]

18. Baker, H.G.; Allen, L.H., Jr.; Boote, K.J.; Jones, P.; Jones, J.W. Response of soybean to air temperature and carbon dioxide concentration. Crop Sci. 1989, 29, 98-105. [CrossRef]

19. Prasad, P.V.V.; Boote, K.J.; Hartwell, L.; Allen, J.R.; Thomas, J.M.G. Super-optimal temperatures are detrimental to peanut (Arachis hypogaea L.) reproductive processes and yield at both ambient and elevated carbon dioxide. Glob. Chang. Biol. 2003, 9, 1775-1787. [CrossRef]

20. Olesen, J.E.; Bindi, M. Co-sequences of climate change for European agricultural productivity, land use and policy. Eur. J. Agron. 2002, 16, 239-262. [CrossRef]

21. Vanaja, M.; Reddy, P.R.; Lakshmi, N.J.; Maheswari, M.; Vagheera, P.; Ratnakumar, P.; Jyothi, M.; Yadav, S.K.; Venkateswarulu, B. Effect of elevated $\mathrm{CO}_{2}$ concentration on growth and yield of blackgram (Vigna mungo L. Hepper)-A rainfed pulse crop. Plant Soil Environ. 2007, 53, 81-88.

22. Hampton, J.G.; Boelt, B.; Rolston, M.P.; Chastain, T.G. Effects of elevated $\mathrm{CO}_{2}$ and temperature on seed quality. J. Agric. Sci. 2013, 151, 154-162. [CrossRef] [PubMed]

23. Farrar, J.F.; Williams, M.L. The effects of increased atmospheric carbon-dioxide and temperature on carbon partitioning, source-sink relations and respiration. Plant Cell Environ. 1991, 14, 819-830. [CrossRef]

24. Dornbos, D.L.J.; Mullen, R.E. Influence of stress during soybean seed fill on seed weight, germination and seedling growth rate. Can. J. Plant Sci. 1991, 71, 373-383. [CrossRef]

25. Wang, J.; Gan, Y.T.; Clarke, F.; McDonald, C.L. Response of chickpea yield to high temperature stress during reproductive development. Crop Sci. 2006, 46, 2171-2178. [CrossRef] 
26. Madan, P.; Jagadish, S.V.K.; Craufurd, P.Q.; Fitzgerald, M.; Lafarge, T.; Wheeler, T.R. Effect of elevated $\mathrm{CO}_{2}$ and high temperature on seed-set and grain quality of rice. J. Environ. Bot. 2012, 63, 3843-3852. [CrossRef] [PubMed]

27. Fairey, D.T.; Hampton, J.G. Forage Seed Production I. Temperate Species; CAB International: Wallingford, UK, 1998.

28. Deckmyn, G.; Caeyenberghs, E.; Ceulemans, R. Reduced UV-B in greenhouses decreases white clover response to enhanced $\mathrm{CO}_{2}$. Environ. Exp. Bot. 2001, 46, 109-117. [CrossRef]

29. Edwards, G.R.; Clark, H.; Newton, P.C.D. The effects of elevated $\mathrm{CO}_{2}$ on seed production and seedling recruitment in a sheep-grazed pasture. Oecologia 2001, 127, 383-394.

30. Wagner, J.; Luscher, A.; Hillebrand, C.; Kobald, B.; Spitaler, N.; Larcher, W. Sexual reproduction of Lolium perenne L. and Trifolium repens $\mathrm{L}$. under free air $\mathrm{CO}_{2}$ enrichment (FACE) at two levels of nitrogen application. Plant Cell Environ. 2001, 24, 957-965. [CrossRef]

31. Maw, B.R.; Jones, C.S.; Newton, P.D.; Hatier, J.-H.B. Elevated atmospheric $\mathrm{CO}_{2}$ alters heading date of perennial ryegrass. Proc. N. Z. Grassl. Assn. 2014, 76, 217-220.

32. Huxman, T.E.; Hamerlynck, E.P.; Smith, S.D. Reproductive allocation and seed production in Bromus madritensis spp. rubens at elevated $\mathrm{CO}_{2}$. Funct. Ecol. 1999, 13, 769-777. [CrossRef]

33. Smith, S.D.; Huxman, T.E.; Zitzer, S.F.; Charlet, T.N.; Housman, D.C.; Coleman, J.S.; Fenstermaker, L.K.; Seemann, J.R.; Nowak, R.W. Elevated $\mathrm{CO}_{2}$ increases productivity and invasive species success in an arid ecosystem. Nature 2000, 408, 79-82. [CrossRef] [PubMed]

34. Thurig, B.; Korner, C.; Stocklin, J. Seed production and seed quality in a calcareous grassland in elevated $\mathrm{CO}_{2}$. Glob. Chang. Biol. 2003, 9, 873-884. [CrossRef]

35. Hikosaka, K.; Kinugasa, T.; Oikawa, S.; Onoda, Y.; Hirose, T. Effects of elevated $\mathrm{CO}_{2}$ concentration on seed production in C3 annual plants. J. Exp. Bot. 2010, 64, 1523-1530. [CrossRef] [PubMed]

36. Miyagi, K.M.; Kinugasa, T.; Hikosaka, K.; Hirose, T. Elevated $\mathrm{CO}_{2}$ concentration, nitrogen use, and seed production in annual plants. Glob. Chang. Biol. 2007, 13, 2161-2170. [CrossRef]

37. Rogers, A.; Ainsworth, E.A.; Leckey, A.D.B. Will elevated carbon dioxide concentration amplify the benefits of nitrogen fixation in legumes? Plant Physiol. 2009, 151, 1009-1016. [CrossRef] [PubMed]

38. Dodd, M.B. Elevated $\mathrm{CO}_{2}$ impacts on grazed pasture: Long-term lessons from the New Zealand FACE. In Proceedings of the 22nd International Grassland Congress, Sydney, Australia, 15-19 September 2013; Michalk, D.L., Millar, G.D., Badgery, W.B., Broadfoot, K.M., Eds.; New South Wales Department of Primary Industry: Sydney, Australia, 2013; pp. 1279-1284.

39. West, J.B.; Hillerislambers, J.; Lee, T.D.; Hobbie, S.E.; Reich, P.B. Legume species identity and soil nitrogen supply determine symbiotic nitrogen-fixation responses to elevated atmospheric $\mathrm{CO}_{2}$. New Phytol. 2005, 167, 523-466. [CrossRef] [PubMed]

40. Thomas, R.G. Reproductive development. In White Clover; Baker, M.J., Williams, W.M., Eds.; CAB International: Wallingford, UK, 1987; pp. 63-124.

41. Thomas, R.G. The influence of environment on seed production capacity in white clover (Trifolium repens L.). I. Controlled environment studies. Aust. J. Agric. Res. 1961, 12, 227-238. [CrossRef]

42. Thomas, R.G. Growth of the white clover plant in relation to seed production. In Herbage Seed Production; Lancashire, J.A., Ed.; Grassland Research and Practice Series No. I; New Zealand Grassland Association: Palmerston North, New Zealand, 1980; pp. 56-63.

43. Norris, I.B. Flowering of contrasting white clover varieties in relation to temperature in controlled environments. Ann. Bot. 1985, 56, 317-322.

44. Langer, R.H.M. How Grasses Grow, 2nd ed.; The Institute of Biology's Studies in Biology, No. 34; Edward Arnold (Publishers) Ltd.: London, UK, 1979.

45. Alberda, T. The effects of cutting, light intensity and night temperature on growth and soluble carbohydrate content of Lolium perenne L. Plant Soil 1957, 8, 199-230. [CrossRef]

46. Aamlid, T.S.; Heide, O.M.; Boelt, B. Primary and secondary induction requirements for flowering of contrasting European varieties of Lolium perenne. Ann. Bot. 2000, 86, 1087-1095. [CrossRef]

47. Purvis, O.N.; Gregory, F.G. Devernalization by high temperature. Nature 1945, 155, 113-114. [CrossRef]

48. Wilson, J.R. Influence of time of tiller origin and of nitrogen level on floral initiation and ear emergence of four pasture species. N. Z. J. Agric. Res. 1959, 2, 915-932. [CrossRef] 
49. Ryle, G.J.A. Effects of daylength and temperature on ear size in S.24 perennial ryegrass. Ann. Appl. Biol. 1965, 55, 107-114. [CrossRef]

50. Rolston, M.P.; Rowarth, J.S; Young, W.C., III; Mueller-Warrant, G.W. Grass seed crop management. In Herbage Seed Production. Temperate Species; Fairey, D.T., Hampton, J.G., Eds.; CAB International: Wallingford, UK, 1997; pp. 105-126.

51. Hampton, J.G.; Hebblethwaite, P.D. The effects of the environment at anthesis on the seed yield and yield components of perennial ryegrass (Lolium perenne L.). cv. S24. J. Appl. Seed Prod. 1983, 1, 21-22.

52. Idso, S.B.; Kimball, B.A. Growth response of carrot and radish to atmospheric $\mathrm{CO}_{2}$ enrichment. Environ. Exp. Bot. 1989, 29, 135-139. [CrossRef]

53. Mortensen, L.M. Effects of elevated $\mathrm{CO}_{2}$ concentration on growth and yield of eight vegetable species in a cool climate. Sci. Hortic. 1994, 58, 177-185. [CrossRef]

54. Wheeler, T.R.; Morison, J.I.L.; Ellis, R.H.; Hadley, P. The effects of $\mathrm{CO}_{2}$, temperature and their interaction on the growth and yield of carrot (Daucus carota L.). Plant Cell Environ. 1994, 17, 1275-1284. [CrossRef]

55. Usuda, H.; Shimogawara, K. The effects of increased atmospheric carbon dioxide on growth, carbohydrates and photosynthesis in radish, Raphanus sativus. Plant Cell Physiol. 1998, 39, 1-7. [CrossRef]

56. Curtis, P.S.; Snow, A.A.; Miller, A.S. Genotype-specific effects of elevated $\mathrm{CO}_{2}$ on fecundity in wild radish (Raphanus raphanistrum). Oecologia 1994, 97, 100-105. [CrossRef]

57. Case, A.L.; Curtis, P.S.; Snow, A.A. Heritable variation in stomatal response to elevated $\mathrm{CO}_{2}$ in wild radish, Raphanus raphanistrum (Brassicaceae). Am. J. Bot. 1998, 85, 253-258. [CrossRef] [PubMed]

58. Quagliotti, L. Effects of different temperatures on stalk development, flowering habit, and sex expression in the carrot Daucas carota L. Euphytica 1967, 16, 83-103. [CrossRef]

59. Gray, D.; Steckel, J.R.A.; Dearman, J.; Brocklehurst, P.A. Some effects of temperature during seed development on carrot (Daucus carota) seed growth and quality. Ann. Appl. Biol. 1988, 112, 367-376. [CrossRef]

60. Sheen, T.F. Effect of day and night temperature variation and of high temperature on devernalization in radish. Acta Hortic. 2000, 514, 157-162.

61. Weibe, J.H.; Habegger, R.; Liebig, H.P. Quantification of vernalization and devernalisation effects for kohl rabi (Brassica oleracea convar. acephala var. gongylodes L.). Sci. Hortic. 1992, 50, 11-20. [CrossRef]

62. Zenkteler, E.; Samordakiewicz, S.; Kaluzewicz, A.; Knaflewski, M. Effect of devernalization on the transition from vegetative to prefloral phase of the broccoli (Brassica oleracea var. italica cv. 'Fiesta') shoot meristem. Acta Agrobot. 2012, 65, 29-36. [CrossRef]

63. El Murabaa, A.I.M. Effects of high temperature on incompatibility in radish. Euphytica 1957, 6, 268-270. [CrossRef]

64. Kumar, P.R.; Yadav, S.K.; Sharma, S.R.; Lal, S.K.; Jha, D.N. Impact of climate change on seed production of cabbage in North Western Himilayas. World J. Agric. Sci. 2009, 5, 18-26.

65. Frenck, G.; van der Linden, L.; Mikkelsen, T.N.; Brix, H.; Jorgensen, R.B. Increased $\left[\mathrm{CO}_{2}\right]$ does not compensate for negative effects on yield caused by higher temperatures and $\left[\mathrm{O}_{3}\right]$ in Brassica napus L. Eur. J. Agron. 2011, 35, 127-134. [CrossRef]

66. Osborne, J.L.; Awmack, C.S.; Clark, S.J.; Williams, I.H.; Mills, V.C. Nectar and flower production in Vicia faba L. (field bean) at ambient and elevated carbon dioxide. Apidologia 1997, 28, 43-55. [CrossRef]

67. Porter, J.R. Rising temperatures are likely to reduce crop yields. Nature 2005, 436, 174. [CrossRef] [PubMed]

68. Prasad, P.V.V.; Boote, K.J.; Hartwell, L.; Allen, J.R.; Thomas, J.M.G. Effects of elevated temperature and carbon dioxide on seed-set and yield of kidney bean (Phaseolus vulgaris L.). Glob. Chang. Biol. 2002, 8, 710-721. [CrossRef]

69. May, P.; Liao, W.; Wu, Y.; Shuai, B.; McCombie, W.R.; Zhang, M.Q.; Liu, Q.A. The effects of carbon dioxide and temperature on microRNA expression in Arabidopsis development. Nat. Commun. 2013, 4, 2145. [CrossRef] [PubMed]

70. Zinn, K.E.; Tunc-Ozdemir, M.; Harper, J.F. Temperature stress and plant sexual reproduction: Uncovering the weakest links. J. Exp. Bot. 2010, 61, 1959-1968. [CrossRef] [PubMed]

71. Barnabas, B.; Jager, K.; Feher, A. The effect of drought and heat stress on reproductive processes in cereals. Plant Cell Environ. 2008, 31, 11-38. [CrossRef] [PubMed]

72. Rusterholz, H.P.; Erhardt, A. Effects of elevated $\mathrm{CO}_{2}$ on flowering phenology and nectar production of nectar plants important for butterflies of calcareous grasslands. Oecologia 1998, 113, 341-349. [CrossRef] 
73. Hoover, S.E.R.; Ladley, J.J.; Shchepetkina, A.A.; Tisch, M.; Gieseg, S.P.; Tylianakis, J.M. Warming, $\mathrm{CO}_{2}$, and nitrogen deposition interactively affect a plant-pollinator mutualism. Ecol. Lett. 2012, 11, 1351-1363. [CrossRef] [PubMed]

74. Baker, H.G.; Baker, I. Floral nectar sugar constituents in relation to pollinator type. In Handbook of Experimental Pollination Biology; Jones, C., Little, R., Eds.; Van Nostrand Reinhold: New York, NY, USA, 1983; pp. 117-141.

75. Hall, A.E. Breeding for adaptation to drought and heat in cowpea. Eur. J. Agron. 2004, 21, 447-454. [CrossRef]

76. Hedhly, A.; Hormaza, J.I.; Herrero, M. Global warming and sexual plant reproduction. Trends Plant Sci. 2008, 14, 30-36. [CrossRef] [PubMed]

77. Koti, S.; Reddy, K.R.; Reddy, V.R.; Kakani, V.G.; Zhao, D. Interactive effects of carbon dioxide, temperature, and ultraviolet-B radiation on soybean (Glycine max L.) flower and pollen morphology, pollen production, germination and tube lengths. J. Exp. Bot. 2005, 56, 725-736. [CrossRef] [PubMed]

78. Prasad, P.V.V.; Boote, K.J.; Hartwell Allen, L., Jr. Adverse high temperature effects on pollen viability, seed set, seed yield and harvest index of grain-sorghum [Sorghum bicolor (L.) Moench] are more severe at elevated carbon dioxide due to higher tissue temperatures. Agric. For. Meteorol. 2006, 139, 237-251. [CrossRef]

79. Marshall, D.L.; Tyler, A.P.; Abrahamson, N.J.; Avritt, J.J.; Barnes, M.G.; Larkin, L.L.; Medeiros, J.S.; Reynolds, J.; Shaner, M.G.M.; Simpson, H.L.; et al. Pollen performance of Raphanus sativus (Brassicaceae) declines in response to elevated $\mathrm{CO}_{2}$. Sex. Plant Reprod. 2010, 23, 325-336. [CrossRef] [PubMed]

80. Conroy, J.; Hocking, P. Nitrogen nutrition of $\mathrm{C} 3$ plants at elevated atmospheric $\mathrm{CO}_{2}$ concentrations. Physiol. Plant. 1993, 89, 570-576. [CrossRef]

81. Boote, K.J.; Allen, L.H.; Prasad, P.V.V.; Baker, J.T.; Gesch, R.W.; Snyder, A.M.; Pan, D.; Thomas, J.M.G. Elevated temperature and $\mathrm{CO}_{2}$ impacts on pollination, reproductive growth, and yield of several globally important crops. J. Agric. Meteorol. 2005, 60, 469-474.

82. Klein, A.M.; Vaissiere, B.E.; Cane, J.H.; Steffan-Dewenter, I.; Cunningham, S.A.; Kremen, C.; Tscharntke, T. Importance of pollinators in changing landscapes for world crops. Proc. R. Soc. B Biol. Sci. 2007, 274, 303-313. [CrossRef] [PubMed]

83. Schweiger, O.; Biesmeijer, J.C.; Bommarco, R.; Hickler, T.; Hulme, P.E.; Klotz, S.; Kuhn, I.; Moora, M.; Neilsen, A.; Ohlemuller, R.; et al. Multiple stressors on biotic interactions: How climate change and alien species interact to affect pollination. Biol. Rev. 2010, 85, 777-795. [CrossRef] [PubMed]

84. Dietlein, D.G. Measurement of carbon dioxide levels in honey bee colonies using a thermistor bridge. Am. Bee J. 1985, 125, 773-774.

85. Ribbands, C.R. Changes in the behaviour of honey-bees following their recovery from anaesthesia. Exp. Biol. 1950, 27, 302-310.

86. Ebadi, R.; Gary, N.E.; Lorenzen, K. Effects of carbon dioxide and low temperature narcosis on honeybees, Apis mellifera. Environ. Entomol. 1980, 9, 144-147. [CrossRef]

87. Buhler, R.; Lanzrein, B.; Wille, H. Influence of temperature and carbon dioxide concentration on juvenile hormone titre and dependent parameters of adult worker honey bees (Apis mellifera L.). J. Insect Physiol. 1983, 29, 885-893. [CrossRef]

88. Willmer, P.G.; Stone, G.N. Behavioral, ecological, and physiological determinants of the activity patterns of bees. Adv. Stud. Behav. 2004, 34, 347-466.

89. Kjohl, M.; Nielsen, A.; Stenseth, N.C. Potential Effects of Climate Change on Crop Pollination; FAO: Rome, Italy, 2011.

90. Deutsch, C.A.; Tewksbury, J.J.; Huey, R.B.; Sheldon, K.S.; Ghalambor, C.K.; Haak, D.C.; Martin, P.R. Impacts of climate warming on terrestrial ecotherms across latitude. Proc. Natl. Acad Sci. USA 2008, 105, 6668-6672. [CrossRef] [PubMed]

91. Simmonds, N.W. Principles of Crop Improvement; Longman: London, UK, 1979.

92. Conner, A.J.; Field, R.J. Herbicide-resistant crops: A new approach to an old problem or a radical new tool? In Herbicide-Resistant Crops and Pastures in Australian Farming Systems; McLean, G.D., Evans, G., Eds.; Bureau of Resource Sciences: Canberra, Australia, 1995; pp. 53-71.

93. Nieuwhof, M. Effect of temperature on the expression of male sterility in Brussels sprouts (Brassica oleracea L. var. gemmifera DC). Euphytica 1986, 17, 265-273.

94. Townsend, C.E. Self-compatibility studies with diploid alsike clover, Trifolium hybridum L., III. Response to temperature. Crop Sci. 1968, 8, 269-272. [CrossRef] 
95. Kendall, W.A.; Taylor, N.L. Effect of temperature on pseudo-self-compatibility in Trifolium pratense L. Theor. Appl. Genet. 1969, 39, 123-126. [CrossRef] [PubMed]

96. Chen, C.C.; Gibson, P.B. Effect of temperature on pollen-tube growth in Trifolium repens after cross- and self-pollination. Crop Sci. 1973, 13, 563-566. [CrossRef]

97. Wilkins, P.W.; Thorogood, D. Breakdown of self-incompatibility in perennial ryegrass at high temperature and its uses in breeding. Euphytica 1992, 64, 65-69.

98. Young, L.W.; Wilen, R.W.; Bonham-Smith, P.C. High temperature stress of Brassica napus during flowering reduces micro-and megagametophyte fertility, induces fruit abortion, and disrupts seed production. J. Exp. Bot. 2004, 55, 485-495. [CrossRef] [PubMed]

99. Gibson, L.R.; Paulsen, G.M. Yield components of wheat grown under high temperature stress during reproductive growth. Crop Sci. 1999, 39, 1841-1846. [CrossRef]

100. Ziska, L.H.; Bunce, J.A. Influence of increasing carbon dioxide concentration on the photosynthetic and growth stimulation of selected C4 crops and weeds. Photosynth. Res. 1997, 54, 199-208. [CrossRef]

101. Huxman, T.E.; Hamerlynck, E.P.; Jordan, D.S.; Salsman, K.L.; Smith, S.D. The effects of parental $\mathrm{CO}_{2}$ environment on seed quality and subsequent seedling performance. Oecologia 1998, 114, 202-208. [CrossRef]

102. Powell, A.A. Seed vigour and its assessment. In Handbook of Seed Science and Technology; Basra, A.S., Ed.; Food Products Press: New York, NY, USA, 2006; pp. 603-648.

103. Halmer, P. Storage management. In The Encylopedia of Seeds: Science, Technology and Uses; Black, M., Bewley, J.D., Halmer, P., Eds.; CAB International: Wallingford, UK, 2006; pp. 659-662.

104. Hill, M.J. The characteristics of grain and seeds and their reaction to climate. In The Drying and Storage of Grain and Herbage Seeds; Hill, M.J., Ed.; Foundation for Arable Research: Lincoln, New Zealand, 1999; pp. 3-19.

105. Probert, R.J.; Hay, F.R. Keeping seeds alive. In Seed Technology and Its Biological Basis; Black, M., Bewley, J.D., Eds.; Sheffield Academic Press: Sheffield, UK, 2000; pp. 375-410.

106. Fenemore, P.; Lauren, D.; Hill, M.J. Pests and diseases: Their role and significance in affecting seed quality. In The Drying and Storage of Grain and Herbage Seeds; Hill, M.J., Ed.; Foundation for Arable Research: Lincoln, New Zealand, 1999; pp. 93-116.

107. Harrington, J.F. Seed storage longevity. In Seed Biology; Kozlowski, T.T., Ed.; Academic Press: New York, NY, USA, 1972; Volume 3, pp. 145-245.

108. Fischer, G.; Shah, M.; Tubiello, N.; van Velhuizen, H. Socio-economic and climate change impacts on agriculture: An integrated assessment, 1990-2080. Philos. Trans. R. Soc. B 2005, 360, 2067-2083. [CrossRef] [PubMed]

109. Hampton, J.G.; Rolston, M.P.; Pyke, N.B.; Green, W. Ensuring the long term viability of the New Zealand seed industry. Agron. N. Z. 2012, 42, 129-140.

110. Olesen, J.E.; Trnka, M.; Kersebaum, K.C.; Skjelvag, A.O.; Seguin, B.; Peltonen-Saino, P.; Rossi, F.; Kozyra, J.; Micale, F. Impacts and adaptation of European crop production systems to climate change. Eur. J. Agron. 2011, 34, 96-112. [CrossRef]

111. Kalra, N.; Chakraborty, D.; Sharma, A.; Rai, H.K.; Jolly, M.; Chander, S.; Kumar, P.R.; Bhadraray, S.; Barman, D.; Mittal, R.B.; et al. Effect of increasing temperature on yield of some winter crops in northwest India. Curr. Sci. 2008, 94, 82-88.

112. Kuchirak, C.J. Contribution of planting date trends to increased maize yields in the Central United States. Agron. J. 2008, 100, 328-336. [CrossRef]

113. Lanning, S.P.; Kephart, K.; Carlson, G.R.; Eckhoff, J.E.; Stougaard, R.N.; Wichman, D.M.; Martin, J.M.; Talbert, L.E. Climate change and agronomic performance of hard red spring wheat from 1950 to 2007. Crop Sci. 2010, 50, 835-841. [CrossRef]

114. Hammer, G.; Singh, V.; Nguyen, C.; van Oosterom, E.; McLean, G.; Zheng, B.; Chapman, S.; Jordan, D. Sowing Date Effects on Yield and High Temperature Risk in Sorghum, 2011. Available online: http:/ /www. grdc.com.au/director/events/researchupdates?item_id=3E6A04D5001209 (accessed on 16 November 2011).

115. Rahman, M.M.; Hampton, J.G.; Hill, M.J. Soybean seed yield as affected by time of sowing in a cool temperature environment. J. New Seeds 2005, 7, 1-15. [CrossRef]

116. Board, J.E.; Hall, U. Premature flowering in soybean yield reductions at nonoptimal planting dates as influenced by temperature and photoperiod. Agron. J. 1984, 76, 700-704. [CrossRef] 
117. Ridge, P.E.; Pye, D.L. The effects of temperature and frost at flowering on the yield of peas grown in a Mediterranean environment. Field Crop. Res. 1985, 12, 339-346. [CrossRef]

118. Parry, M.L. (Ed.) Assessment of Potential Effects and Adaptations for Climate Change in Europe; The Europe ACACIA Project, Jackson Environment Institute, University of East Anglia: Norwich, UK, 2000.

119. Cairns, J.E.; Hellin, J.; Sonder, K.; Araus, J.L.; MacRobert, J.F.; Thierfelder, C.; Prasanna, B.M. Adapting maize production to climate change in sub-Sarharan Africa. Food Secur. 2013, 5, 345-360. [CrossRef]

120. Prasanna, B.M.; Chaikam, V.; Mahuku, G. Doubled Haploid Technology in Maize Breeding: Theory and Practice; CIMMYT: Mexico City, Mexico, 2012.

121. Varshney, R.K.; Bansal, K.C.; Aggarwal, P.K.; Datta, S.; Craufurd, P.Q. Agricultural biotechnology for crop improvement in a variable climate: Hope or hype? Trends Plant Sci. 2011, 16, 363-371. [CrossRef] [PubMed]

122. Ortiz, R. Crop genetic engineering under global climate change. Ann. Arid Zone 2008, 47, 1-12.

123. Wahid, A.; Gelani, S.; Ashraf, M.; Foolad, M.R. Heat tolerance in plants: An overview. Environ. Exp. Bot. 2007, 61, 199-223. [CrossRef]

124. Tewolde, H.; Fernandez, C.J.; Erickson, C.A. Wheat cultivars adapted to post-heading high temperature stress. J. Agron. Crop Sci. 2006, 192, 111-120. [CrossRef]

125. Salem, M.A.; Kakani, V.G.; Koti, S.; Reddy, K.R. Pollen-based screening of soybean genotypes for high temperature. Crop Sci. 2007, 47, 219-231. [CrossRef]

126. Bannayan, M.; Tojosoler, C.M.; Garcia, Y.; Garcia, A.; Guerra, L.C.; Hoogenboom, G. Interactive effects of elevated $\mathrm{CO}_{2}$ and temperature on growth and development of a short-and long-season peanut cultivar. Clim. Chang. 2009, 93, 389-406. [CrossRef]

127. Craufurd, P.Q.; Prasad, P.V.V.; Summerfield, R.J. Dry matter production and rate of change of harvest index at high temperature in peanut. Crop Sci. 2002, 42, 146-151. [CrossRef] [PubMed]

128. Porch, T.G.; Jahn, M. Effect of high-temperature stress on microsporogenesis in heat-sensitive and heat-tolerant genotypes of Phaseolus vulgaris. Plant Cell Environ. 2001, 24, 723-731. [CrossRef]

129. Ahmed, F.E.; Hall, A.E.; Madore, M.A. Interactive effects of high temperature and elevated carbon dioxide concentration on cowpea (Vigna unguiculata L. Walp.). Plant Cell Environ. 1993, 16, 835-842. [CrossRef]

130. Kakani, V.G.; Reddy, K.R.; Koti, S.; Wallace, T.P.; Prasad, P.V.V.; Reddy, V.R.; Zhao, D. Differences in in vitro pollen germination and pollen tube growth of cotton cultivars in response to high temperature. Ann. Bot. 2005, 96, 59-67. [CrossRef] [PubMed]

131. Dyck, J.A.; Matus-Cadiz, M.A.; Hucl, P.; Talbert, L.; Hunt, T.; Duboc, J.P.; Noss, H.; Clayton, G.; Dodd, J.; Quick, J. Agronomic performance of hard red spring wheat lines sensitive and insensitive to photoperiodism. Crop. Sci. 2004, 44, 1976-1981. [CrossRef]

132. Blake, N.K.; Lanning, S.P.; Martin, J.M.; Doyle, M.; Sherman, J.D.; Naruoka, Y.; Talbert, L.E. Effect of variation for major growth habit genes on maturity and yield in five spring wheat populations. Crop Sci. 2009, 49, 1211-1220. [CrossRef]

133. Habash, D.Z.; Kehel, Z.; Nachit, M. Genomic approaches for designing durum wheat ready for climate change with a focus on drought. J. Exp. Bot. 2009, 60, 2805-2815. [CrossRef] [PubMed]

134. Bita, C.E.; Gerats, T. Plant tolerance to high temperature in a changing environment: Scientific fundamentals and production of heat stress-tolerant crops. Front. Plant Sci. 2013, 4, 1-18. [CrossRef] [PubMed]

135. Hong, S.W.; Lee, U.; Vierling, E. Arabidopsis hot mutants define multiple functions required for acclimation to high temperature. Plant Physiol. 2003, 132, 757-767. [CrossRef] [PubMed]

136. Roy, S.J.; Tucker, E.J.R.; Tester, M. Genetic analysis of abiotic stress tolerance in crops. Curr. Opin. Plant Biol. 2011, 14, 232-239. [CrossRef] [PubMed]

137. Paliwal, R.; Roder, M.S.; Kumar, U.; Srivastava, J.; Joshi, A.K. QTL mapping of terminal heat tolerance in hexaploid wheat (T. aestivum L.). Theor. Appl. Genet. 2012, 125, 561-575. [CrossRef] [PubMed]

138. Giorno, F.; Wolters-Arts, M.; Mariani, C.; Rieu, I. Ensuring reproduction at high temperatures: The heat stress response during anther and pollen development. Plants 2013, 2, 489-506. [CrossRef] [PubMed]

139. Manderscheid, R.; Weigel, J. Photosynthetic and growth responses of old and modern spring wheat cultivars to atmospheric $\mathrm{CO}_{2}$ enrichment. Agric. Ecosyst. Environ. 1997, 64, 65-73. [CrossRef]

140. Ziska, L.H.; Morris, C.F.; Goins, E.W. Quantitative and qualitative evaluation of selected wheat varieties released since 1903 to increasing atmospheric carbon dioxide: Can yield sensitivity to carbon dioxide be a factor in wheat performance? Glob. Chang. Biol. 2004, 10, 1810-1819. [CrossRef] 
141. Collins, N.C.; Tardieu, F.; Tuberosa, R. Quantitative trait loci and crop performance under abiotic stress: Where do we stand? Plant Physiol. 2008, 147, 469-486. [CrossRef] [PubMed]

142. Reif, J.C.; Zhang, P.; Dreisigacker, S.; Warburton, M.L.; van Ginkel, M.; Hoisington, D.; Bohn, M.; Melchinger, A.E. Wheat genetic diversity trends during domestication and breeding. Theor. Appl. Genet. 2005, 110, 859-864. [CrossRef] [PubMed]

143. Von Korff, M.; Radovic, S.; Choumane, W.; Stamati, K.; Udupa, S.M.; Grandol, S.; Ceccarelli, S.; MacKay, I.; Powell, W.; Baum, M.; et al. Asymetric allele-specific expression in relation to developmental variations and drought stress in barley hybrids. Plant J. 2009, 59, 14-26. [CrossRef] [PubMed]

144. Carena, M.J.; Bergman, N.; Riveland, N.; Eriksmoen, E.; Halvorson, M. Breeding maize for higher yield and quality under drought stress. Maydica 2009, 54, 287-296.

145. Cairns, J.E.; Sonder, K.; Zaidi, P.H.; Verhulst, N.; Mahuku, G.; Babu, R.; Nair, S.K.; Das, B.; Govaerts, B.; Vinayan, M.T.; et al. Maize production in a changing climate. Adv. Agron. 2012, 144, 51-58.

146. Westengen, O.T.; Brysting, A.K. Crop adaptation to climate change in the semi-arid zone in Tanzania: The role of genetic resources and seed systems. Agric. Food Secur. 2014, 3, 3. [CrossRef]

147. Pariyar, D.; Hampton, J.G. Base Line Survey—Cool Season Crop Improvement Programme, Nepal; New Zealand Ministry of Foreign Affairs and Trade: Kathmandu, Nepal, 2015.

148. Setimila, P.; MacRobert, J.; Atlin, G.N.; Magorokosho, C; Tarekegne, A.; Makumbi, D.; Taye, G. Performance of elite maize varieties tested in on-farm trials in eastern and southern Africa. In Proceedings of the ASA, CSSA, and SSSA International Annual Meetings, Cincinnati, OH, USA, 21-24 October 2012.

149. Cairns, J.E.; Crossa, C.; Zaidi, P.H.; Grudloyma, P.; Sanchez, C.; Araus, J.L.; Makumbi, D.; Magorokosho, C.; Bänziger, M.; Menkir, A.; et al. Identification of drought, heat, and combined drought and heat tolerance donors in maize (Zea mays L.). Crop Sci. 2013, 53, 1335-1346. [CrossRef]

150. Barnett, C.; Chisuo, M.; Pinto, Y. Country case studies on the pass value chain strategy/approach and its impact/effect on small holder farmer yields in Africa. In East Africa Synthesis Report (Kenya, Tanzania, Uganda); Agriculture Learning and Impact Network: London, UK, 2011.

151. Adapting Agriculture to Climate Change. Royal Botanic Gardens, Kew, UK. Available online: http://www.kew.org/science-conservation/reserawch-data/science-directory/projects/ada (accessed on 29 February 2016).

(C) 2016 by the authors; licensee MDPI, Basel, Switzerland. This article is an open access article distributed under the terms and conditions of the Creative Commons Attribution (CC-BY) license (http://creativecommons.org/licenses/by/4.0/). 